\title{
Schistosomiasis-Induced Experimental Pulmonary Hypertension
}

\section{Role of Interleukin-13 Signaling}

Brian B. Graham, ${ }^{*}$ Margaret M. Mentink-Kane, ${ }^{\dagger}$ Hazim El-Haddad, ${ }^{\ddagger}$ Shawn Purnell, ${ }^{\S}$ Li Zhang, ${ }^{*}$ Ari Zaiman, "Elizabeth F. Redente," David W. H. Riches," Paul M. Hassoun, ${ }^{\text {" }}$ Angela Bandeira, ${ }^{* \star}$ Hunter C. Champion, ${ }^{\dagger \dagger}$ Ghazwan Butrous, ${ }^{\ddagger \neq}$ Thomas A. Wynn, ${ }^{\dagger}$ and Rubin M. Tuder*

\begin{abstract}
From the Program in Translational Lung Research,, Pulmonary and Critical Care Medicine, University of Colorado, Denver, Colorado; the Immunopathogenesis Section, ${ }^{\dagger}$ Laboratory of Parasitic Diseases/National Institute of Allergy and Infectious Diseases, National Institutes of Health, Bethesda, Maryland; the Departments of Cardiology, ${ }^{\ddagger}$ and Pulmonary and Critical Care Medicine, "Iohns Hopkins University, Baltimore, Maryland; the Department of Pathology and Laboratory Medicare, ${ }^{\S}$ University of California at Davis, Davis, California; the Program in Cell Biology," National Jewish Health, Denver, Colorado; the Department of Cardiology, ** Federal University of Pernambuco, Recife, Brazil; the Department of Cardiology," University of Pittsburgh, Pittsburgh, Pennsylvania; and the Pulmonary Vascular Research Institute, ${ }^{\#}$ University of Kent, Kent, United Kingdom
\end{abstract}

The mechanisms underlying schistosomiasis-induced pulmonary hypertension ( $\mathrm{PH})$, one of the most common causes of $\mathrm{PH}$ worldwide, remain unclear. We sought to determine whether Schistosoma mansoni causes experimental PH associated with pulmonary vascular remodeling in an interleukin (IL)-13-dependent manner. IL-13R $\alpha 1$ is the canonical IL-13 signaling receptor, whereas $I L-13 R \alpha 2$ is a competitive nonsignaling decoy receptor. Wild-type, IL-13R $\alpha 1^{-/-}$, and IL-13R $\alpha 2^{-/-}$C57BL/6J mice were percutaneously infected with $S$. mansoni cercariae, followed by i.v. injection of eggs. We assessed $\mathrm{PH}$ with right ventricular catheterization, histological evaluation of pulmonary vascular remodeling, and detection of IL-13 and transforming growth factor- $\beta$ signaling. Infected mice developed pulmonary peri-egg granulomas and arterial remodeling involving predominantly the vascular media. In addition, gain-of-function IL-13R $\alpha 2^{-/-}$mice had exacerbated vascular remodeling and PH. Mice with loss of II-13R $\alpha 1$ function did not develop PH and had reduced pulmonary vascular remodeling. Moreover, the expression of resistin-like molecule- $\alpha$, a target of IL-13 signaling, was increased in infected wild-type and IL-13R $\alpha 2^{-/-}$but not IL-13R $\alpha 1^{-/-}$mice. Phosphorylated Smad2/3, a target of transforming growth factor- $\beta$ signaling, was increased in both infected mice and humans with the disease. Our data indicate that experimental schistosomiasis causes $\mathbf{P H}$ and potentially relies on up-regulated IL-13 signaling. (Am J Pathol 2010, 177:1549-1561; DOI: 10.2353/ajpath.2010.100063)

Pulmonary hypertension $(\mathrm{PH})$ is a frequent and potentially fatal sequel to several chronic lung, collagen vascular, and liver diseases. ${ }^{1}$ Furthermore, pulmonary arterial hypertension (PAH) occurs in a fraction of patients with HIV infection, and idiopathic $\mathrm{PAH}$ has been linked to the human herpesvirus type $8 .^{2}$ The pathogenesis of $\mathrm{PH}$ involves an imbalance of vascular cell proliferation vis-àvis cell death, driven by excessive growth factor stimulation, including transforming growth factor (TGF)- $\beta$ family signaling, ${ }^{3}$ platelet derived growth factor, ${ }^{4}$ and more recently, Notch receptor signaling. ${ }^{5}$ In idiopathic $\mathrm{PAH}$, dysregulation of TGF- $\beta$ signaling is central to the pathobiology of the disease, including mutations of bone mor-

Supported by Cardiovascular Medical Research Fund, the Translational Lung Research Program at the University of Colorado, the Parker B. Francis Fellowship Program, the Intramural Research Program of National Institute of Allergy and Infectious Diseases, National Institutes of Health, and National Institutes of Health grants F32HL095274 and NIH R01HL068628.

Accepted for publication May 13, 2010

Supplemental material for this article can be found on http://ajp. amjpathol.org.

Address reprint requests to Brian B. Graham, M.D., Program in Translational Lung Research, Division of Pulmonary Sciences and Critical Care Medicine, University of Colorado, Denver, Research 2 - 9th floor; Mail stop C-272, 12700 East 19th Ave, Aurora, CO 80045. E-mail: brian.graham@ ucdenver.edu. 
phogenetic protein receptor 2. ${ }^{6}$ Recent evidence has linked the cellular events underlying pulmonary vascular remodeling to hypoxia-like metabolic alterations, largely driven by hypoxia-inducible factor- $1 \alpha$ in both experimental models ${ }^{7}$ and in the human disease. ${ }^{8}$ Moreover, both the human disease and experimental models have a variable contribution by inflammatory cells, whose precise pathogenetic role has not been clarified thus far.

Schistosomiasis is one of the most common causes of $\mathrm{PAH}$, occurring in 2 to $5 \%$ of the over 200 million individuals chronically infected worldwide. ${ }^{9}$ Schistosoma are snail-borne trematodes that percutaneously infect individuals, transiently pass through the lungs, and migrate to the portal venous system where they reproduce and release eggs. Four to $8 \%$ of those chronically infected develop hepatosplenic disease, in which the host immunological response and disruption of portal hepatic blood flow to the egg antigens leads to progressive liver fibrosis and portal hypertension. ${ }^{10}$ Over time, the increased pressure causes opening of portosystemic shunts, allowing the passage of eggs to the pulmonary arterial circulation. ${ }^{11}$ The pulmonary vascular pathology is associated with progressive clinical $\mathrm{PH}$ and right heart failure. $\mathrm{PH}$ almost exclusively occurs in those infected with the species Schistosoma mansoni rather than the other endemic species Schistosoma japonicum and Schistosoma hematobium.

There has been an intense effort to better understand the pathogenesis of liver fibrosis due to schistosomiasis, uncovering a type 2 helper $\mathrm{T}$ cell (Th-2) predominant immunological response, highlighted by the involvement of interleukin (IL)-4 and IL-13 as key mediators of granuloma size, and most importantly, of the fibrogenic response with liver injury. ${ }^{12}$ More recently, Andrade has noted that the portal fibrosis may arise from a destruction of the portal vein, with occlusive lesions. ${ }^{10}$ Of note, experimental $\mathrm{PH}$ is also associated with early endothelial cell apoptosis, ${ }^{6}$ which might lead to abnormal endothelial proliferation, genetic instability, and occlusive lesions. ${ }^{13}$

Despite the focus on the immunological and hepatic alterations caused by the parasite in humans and the growing realization of the epidemiological importance of schistosomiasis-associated $\mathrm{PAH}$, little is known regarding the pathogenesis of this complication related to the parasite infection. In a subset of patients with the hepatosplenic form of schistosomiasis, a concurrent pulmonary arterial vasculopathy develops with medial and intimal lesions, including plexiform lesions reminiscent of the pathology of idiopathic $\mathrm{PAH} .{ }^{14}$ This remodeling involves an excessive number of smooth muscle cells in the intima and media and proliferation of endothelial cells. ${ }^{14}$ Mice chronically infected with schistosomes can develop pulmonary peri-egg granulomas and pulmonary vascular remodeling, but have not been previously demonstrated to develop $\mathrm{PH} .{ }^{15}$ The acute infection in mice causes granulomas reliant on a Th-1 response, while chronic infection transitions to a Th-2 response with increased $\mathrm{IL}-13$ and larger granulomas often with fibrosis. ${ }^{16,17} \mathrm{~A}$ downstream product of the IL-4 and IL-13 signaling pathways, resistin-like molecule (RELM)- $\alpha$ (also called found in inflammatory zone-1, hypoxia-induced mitogenic fac- tor, and Retnla), was recently identified as an important regulator of the host inflammatory response in both the liver and the lungs, as mice lacking RELM- $\alpha$ have larger granulomas. ${ }^{18}$ In multiple secondary forms of severe $\mathrm{PH}$, including connective tissue disease and schistosomiasis-associated $\mathrm{PH}$, inflammation likely underlies the pathogenesis. ${ }^{19}$ Whereas Schistosoma eggs are usually found within granulomas, their direct role or connection with ensuing inflammation in the pathogenesis of schistosomiasis-associated $\mathrm{PH}$ remains unclear.

Although most of the experimental models of $\mathrm{PH}$ involve challenge with chronic hypoxia or endothelial cell toxicity with the alkaloid monocrotaline pyrrole, schistosomiasis-associated $\mathrm{PH}$ might involve the direct interplay of inflammatory cells and cytokines with well-known aforementioned signaling pathways that control pulmonary vascular reactivity and/or remodeling. The interactions between cell signaling induced by the peri-egg granulomatous response and the altered cellular and molecular framework underlying pulmonary vasculopathy, including the role of altered TGF- $\beta$ signaling and imbalance between vascular cell death versus proliferation, have not been studied. The mouse model of schistosomiasis-induced $\mathrm{PH}$ offers a unique system to interrogate the interplay of growth factors that control pulmonary vascular cell function and Th-2 signaling.

In the present study, we postulated that schistosome eggs and the ensuing Th-2 inflammatory response they induce are key drivers in experimental $\mathrm{PH}$ caused by $S$. mansoni. To address this hypothesis, we developed a model system to test whether mice infected with S. mansoni develop $\mathrm{PH}$ and pulmonary vascular remodeling; furthermore, we interrogated the potential participation of Th-2-dependent cytokines and growth factors that may have led to the pulmonary vascular remodeling, including RELM- $\alpha$ and TGF- $\beta$. We used wild-type C57BI6/J and two genetically modified mice: IL-13R $\alpha 1^{-1-}$, lacking the canonical IL-13 receptor resulting in a loss-of-function of IL-13 signaling, and mice lacking the soluble and membranebound "decoy" IL-13 receptor (IL-13R $\alpha 2^{-/-}$), which results in a gain-of-function for IL-13 signaling. We also analyzed human pulmonary autopsy tissue from patients with schistosomiasis-associated $\mathrm{PH}$ to compare signaling pathways between the mouse model and human disease.

\section{Materials and Methods}

\section{Animals}

Breeding pairs of C57BL/6J IL-13R $\alpha 1^{-1-}$ mice (N10) were provided by Regeneron Pharmaceuticals (Tarrytown, NY), and C57BL/6J IL-13R $\alpha 2^{-1-}$ mice (N10) were provided by Wyeth Research (Cambridge, MA). The phenotypes of these knockout models have been described previously. ${ }^{17,20}$ The wild-type control mice were also of the C57BL/6J background and were purchased from Taconic. All mice were bred and housed under specific pathogen-free conditions in an American Association for the Accreditation of Laboratory Animal Care-approved 
Table 1. Reagents for Immunoblots

\begin{tabular}{|c|c|c|c|c|}
\hline Immunoblot & Block & Primary antibody* & Secondary antibody & Tertiary reagent \\
\hline $\begin{array}{l}\text { RELM- } \alpha \\
\text { p-Smad2/3 }\end{array}$ & $\begin{array}{l}\text { StartingBlock } 2 \text { hours } \\
\text { at room temperature } \\
\text { (Thermo Scientific }\end{array}$ & $\begin{array}{l}\text { 1/50,000 Abcam } 39626 \\
\text { 1/2,000 Cell Signaling } \\
\text { Technology } 3101\end{array}$ & \multirow{6}{*}{$\begin{array}{l}\text { Horseradish peroxidase-bound } \\
\text { goat anti-rabbit } 1 / 50001 \\
\text { hour at room temperature } \\
\text { (Vector Laboratories PI-1000) }\end{array}$} & \multirow{6}{*}{$\begin{array}{l}\text { Enhanced chemiluminescence } \\
\text { detection } 5 \text { minutes at room } \\
\text { temperature (GE Healthcare, } \\
\text { RPN2106) }\end{array}$} \\
\hline Smad2/3 & 37542) & $\begin{array}{l}\text { 1/2,000 Cell Signaling } \\
\text { Technology } 3102\end{array}$ & & \\
\hline $\mathrm{p}-\mathrm{ERK} 1 / 2$ & & $\begin{array}{l}\text { 1/2,000 Cell Signaling } \\
\text { Technology } 9101\end{array}$ & & \\
\hline ERK $1 / 2$ & & $\begin{array}{l}\text { 1/2,000 Cell Signaling } \\
\text { Technology } 9102\end{array}$ & & \\
\hline TGF- $\beta$ & & $\begin{array}{l}\text { 1/2,000 Cell Signaling } \\
\text { Technology } 3711\end{array}$ & & \\
\hline$\beta$-Actin & & $\begin{array}{l}\text { 1/20,000 Cell Signaling } \\
\text { Technology } 4967 \\
\text { (also used } 1 / 5,000 \text { for } \\
1 \text { hour at room } \\
\text { temperature) }\end{array}$ & & \\
\hline
\end{tabular}

${ }^{*}$ All primary antibodies incubated overnight at $4{ }^{\circ} \mathrm{C}$ unless otherwise stated.

facility. All experimental procedures in rodents were approved by the Animal Care and Use Committees at the National Institutes of Health, Johns Hopkins University, and the University of Colorado. All experiments were performed in a coded format, with the investigators lacking knowledge of the specific experimental group identifiers before final data reporting.

\section{Schistosomiasis Infection}

S. mansoni cercariae and eggs were obtained from the Biomedical Research Institute (Rockville, MD), and the mice were percutaneously infected with cercariae and intravenously challenged with S. mansoni eggs as described previously. ${ }^{21}$ Briefly, percutaneous infection was performed by placing the mouse tail in a vial containing 30 to 35 cercariae for 30 minutes. Fifty-five days later, mice were challenged intravenously by injecting 5000 viable eggs suspended in $0.5 \mathrm{ml}$ of sterile saline into the tail vein. The intravenous challenge with eggs mimics the deposition of eggs in the lung by collateral shunts, which normally form in chronically infected mice.

\section{Assessment of $\mathrm{PH}$}

Sixty-two days after cercarial infection and 7 days after i.v. egg administration, measurement of the right ventricular pressure was performed as described previously. ${ }^{22}$ Briefly, mice were anesthetized with isofluorane and ventilated through a transtracheal catheter. Before cardiac catheterization a right jugular catheter was placed and $0.2 \mathrm{ml}$ of $5 \%$ albumin instilled. The abdominal and thoracic cavities were opened, and a four-electrode pressure-volume catheter (Scisense model FTS-1212B-4518, London, Ontario, Canada) was placed through the right ventricle apex to transduce the pressure. The blood was flushed out of the lungs, the right bronchus was sutured, and $2 \%$ agarose instilled into the left lung through the transtracheal catheter. The left lung was removed, formalin-fixed, and processed for paraffin embedding. The right lung was removed and frozen. The right ventricle free wall was dissected off of the heart, weighed relative to the septum and left ventricle, and then formalin-fixed and paraffin-embedded.

\section{Egg Burden Quantification}

The number of $S$. mansoni eggs present in the mouse lung tissue was determined as previously described. ${ }^{23}$ Briefly, 20 to $30 \mathrm{mg}$ of frozen right lung tissue was digested in $4 \%$ potassium hydroxide for 18 hours at $33^{\circ} \mathrm{C}$, and the number of eggs present in aliquots of the digest was counted.

\section{Immunoblotting, Immunostaining, and Protein Quantification}

A sample of the right lung frozen tissue was macerated and sonicated in PBS containing anti-proteases, and 20 $\mu \mathrm{g}$ of protein from each sample was used to detect specific proteins by Western blot using the reagents listed in the Table 1. Double-antibody sandwich enzymelinked immunosorbent assays were used to quantify cytokine levels in the tissue lysates using the following kits: IL-13 (M1300CB; R\&D Systems, Minneapolis, MN), TGF- $\beta 1$ (MB100B; R\&D Systems), and tumor necrosis factor (TNF)- $\alpha$ (DY410; R\&D Systems), and following the manufacturer's recommended protocols. Immunohistochemistry, immunofluorescence, and terminal deoxynucleotidyl transferase-mediated dUTP nick-end labeling staining was performed using the reagents listed in the Table 2. Images were acquired with a Nikon Eclipse E800 microscope with filter wheels, a color charge-coupled device camera (Nikon, Melville, NY) and a cooled black and white charge-coupled device camera (Photometrics, Tucson, AZ). Images selected for presentation and analysis were representative of the findings seen in each model, and granulomas were selected with only a single egg nidus visible.

\section{Granuloma Volume Assessment}

The granuloma volumes were measured using the rotator sterologic method. ${ }^{24}$ Briefly, paraffin-embedded tissue 
Table 2. Reagents for Immunostains on Mouse Tissue

\begin{tabular}{|c|c|c|c|c|c|}
\hline Immunostain & Antigen retrieval & Block & Primary antibody & Secondary antibody & Tertiary reagent \\
\hline $\begin{array}{l}\text { Thrombomodulin } \\
\text { (CD141) }\end{array}$ & $\begin{array}{l}\text { Citrate buffer } 30 \text { minutes } \\
\text { in steamer (Vector } \\
\mathrm{H}-3300)\end{array}$ & $\begin{array}{l}\text { 10\% Horse serum in } \\
\text { 1/1 5\% BSA: } \\
\text { Superblock } \\
\text { (ScyTek AAA5000) } \\
1 \text { hour at room } \\
\text { temperature }\end{array}$ & $\begin{array}{c}\text { 1/1000 } 1 \text { hour at room } \\
\text { temperature (R\&D } \\
\text { Systems AF3894) }\end{array}$ & $\begin{array}{l}\text { 1/200 AF594 Donkey } \\
\text { anti-goat (Invitrogen } \\
\text { A11058) } 1 \text { hour at } \\
\text { room temperature }\end{array}$ & None \\
\hline $\begin{array}{l}\text { Proliferating cell nuclear } \\
\qquad \mathrm{Ag}\end{array}$ & $\begin{array}{l}\text { Citrate buffer } 30 \text { minutes } \\
\text { in steamer (Vector } \\
\mathrm{H}-3300)\end{array}$ & $\begin{array}{l}\text { 10\% Horse serum in } \\
\text { 1/1 5\% BSA: } \\
\text { Superblock } \\
\text { (ScyTek AAA5000) } \\
1 \text { hour at room } \\
\text { temperature }\end{array}$ & $\begin{array}{l}\text { 1/50 } 1 \text { hour at room } \\
\text { temperature (Santa } \\
\text { Cruz Biotechnology } \\
\text { 7907) }\end{array}$ & $\begin{array}{l}\text { 1/200 AF488 Donkey } \\
\text { anti-Rabbit } \\
\text { (Invitrogen A21206) } \\
1 \text { hour at room } \\
\text { temperature }\end{array}$ & None \\
\hline Macrophage-3 & $\begin{array}{l}\text { Borg buffer } 30 \text { minutes in } \\
\text { steamer (Biocare } \\
\text { BD1000G1) }\end{array}$ & $\begin{array}{l}\text { 10\% Goat Serum in } \\
\text { 1:15\% BSA: } \\
\text { Superblock } \\
\text { (ScyTek AAA5000) } \\
\text { 1 hour at room } \\
\text { temperature }\end{array}$ & $\begin{array}{l}\text { 1/50 } 1 \text { hour at room } \\
\text { temperature }(\mathrm{BD} \\
\text { Pharmingen } 550292)\end{array}$ & $\begin{array}{l}\text { 1/300 AF488 Goat anti- } \\
\text { Rat (Invitrogen } \\
\text { A11006) } 1 \text { hour at } \\
\text { room temperature }\end{array}$ & \\
\hline $\begin{array}{l}\text { Pro-surfactant protein C } \\
\quad \text { (Pro-SPC) }\end{array}$ & $\begin{array}{l}\text { Citrate buffer } 30 \text { minutes } \\
\text { in steamer (Vector } \\
\text { Laboratories } \mathrm{H}-3300 \text { ), } \\
\text { then avidin } 10 \text { minutes, } \\
\text { then Biotin } 10 \text { minutes }\end{array}$ & $\begin{array}{l}5 \% \text { Horse Serum in } \\
\text { PBS } 1 \text { hour at } \\
\text { room temperature }\end{array}$ & $\begin{array}{l}\text { 1/200 } 1 \text { Hour at room } \\
\text { temperature (Santa } \\
\text { Cruz Biotechnology } \\
7705)\end{array}$ & $\begin{array}{l}\text { 1/100 Biotinylated } \\
\text { donkey anti-Goat } \\
\text { (Abcam 6578) } 1 \\
\text { hour at room } \\
\text { temperature }\end{array}$ & None \\
\hline$\alpha$-Smooth muscle actin & $\begin{array}{l}\text { Mouse on Mouse (MOM) } \\
\text { kit blocking solution } \\
\text { (Vector Laboratories } \\
\text { BMK-2202) } 1 \text { hour at } \\
\text { room temperature }\end{array}$ & $\begin{array}{l}\text { 1/100 } 30 \text { minutes at } \\
\text { room temperature } \\
\text { (DakoCytomation } \\
\text { M0851) }\end{array}$ & $\begin{array}{l}\text { MOM Biotinylated anti- } \\
\text { Mouse Reagent } \\
\text { (Vector Laboratories } \\
\text { BMK-2202) } 10 \\
\text { minutes at room } \\
\text { temperature }\end{array}$ & $\begin{array}{l}\text { Texas Red-Strepavidin } \\
\text { 1/2000 (Invitrogen } \\
\text { S872) }\end{array}$ & None \\
\hline Major basic protein & $\begin{array}{l}\text { Citrate buffer } 30 \text { minutes } \\
\text { in steamer (Vector } \\
\text { Laboratories } \mathrm{H}-3300 \text { ), } \\
\text { then Pepsin } 10 \\
\text { minutes at room } \\
\text { temperature (Invitrogen } \\
\text { 00-3009), then avidin } \\
10 \text { minutes, then Biotin } \\
10 \text { minutes }\end{array}$ & $\begin{array}{l}1.5 \% \text { Rabbit Serum } \\
\text { in PBS } 1 \text { hour at } \\
\text { room temperature }\end{array}$ & $\begin{array}{l}\text { 1/500 } 1 \text { hour at room } \\
\text { temperature } \\
\text { (antibody courtesy of } \\
\text { Lee Lab, Mayo } \\
\text { Clinic) }\end{array}$ & $\begin{array}{l}\text { 1/100 Biotin-Bound } \\
\text { Rabbit anti-Rat } \\
\text { (DakoCytomation } \\
\text { E0468) } 1 \text { hour at } \\
\text { room temperature }\end{array}$ & $\begin{array}{l}\text { Strepavidin-horseradish } \\
\text { peroxidase (Vector } \\
\text { Laboratories SA- } \\
\text { 5704), then DAB } 5 \\
\text { minutes, then } \\
\text { hematoxylin }\end{array}$ \\
\hline CD45 & $\begin{array}{l}\text { Citrate buffer } 30 \text { minutes } \\
\text { in steamer (Vector } \\
\mathrm{H}-3300 \text { ) }\end{array}$ & $\begin{array}{l}10 \% \text { Horse Serum in } \\
\text { PBS } 1 \text { hour at } \\
\text { room temperature }\end{array}$ & $\begin{array}{c}\text { 1/400 } 1 \text { Hour at room } \\
\text { temperature (R\&D } \\
\text { Biosystems AF114) }\end{array}$ & $\begin{array}{l}\text { 1/200 AF594 Donkey } \\
\text { anti-Goat (Invitrogen } \\
\text { A11058) } 1 \text { hour at } \\
\text { room temperature or } \\
\text { 1/200 AF488 } \\
\text { Donkey anti-Goat } \\
\text { (Invitrogen A11055) } \\
1 \text { hour at room } \\
\text { temperature }\end{array}$ & None \\
\hline $\operatorname{RELM}-\alpha$ & $\begin{array}{l}\text { Citrate buffer } 30 \text { minutes } \\
\text { in steamer (Vector } \\
\mathrm{H}-3300 \text { ) }\end{array}$ & $\begin{array}{l}5 \% \text { Horse Serum in } \\
\text { PBS } 1 \text { hour at } \\
\text { room temperature }\end{array}$ & $\begin{array}{l}\text { 1/200 overnight at } 4^{\circ} \mathrm{C} \\
\quad(\text { Abcam } 39626)\end{array}$ & $\begin{array}{l}\text { 1/100 AF488 Donkey } \\
\text { anti-Rabbit } \\
\text { (Invitrogen A21206) } \\
1 \text { hour at room } \\
\text { temperature }\end{array}$ & None \\
\hline p-Smad2/3 & $\begin{array}{l}\text { Citrate buffer } 30 \text { minutes } \\
\text { in steamer (Vector } \\
\mathrm{H}-3300 \text { ) }\end{array}$ & $\begin{array}{l}5 \% \text { Horse Serum in } \\
\text { PBS } 1 \text { hour at } \\
\text { room temperature }\end{array}$ & $\begin{array}{l}\text { 1/100 overnight at } \\
\text { 4degC (Cell } \\
\text { Signaling } \\
\text { Technology 3101) }\end{array}$ & $\begin{array}{l}\text { 1/100 AF488 Donkey } \\
\text { anti-Rabbit } \\
\text { (Invitrogen A21206) } \\
1 \text { hour at room } \\
\text { temperature }\end{array}$ & None \\
\hline $\begin{array}{l}\text { Lectin from Bandeiraea } \\
\text { Simplicifolia } \\
\text { (tetramethylrhodamine } \\
\text { isothiocyanate-bound) }\end{array}$ & $\begin{array}{l}\text { Citrate buffer } 30 \text { minutes } \\
\text { in steamer (Vector } \\
\mathrm{H}-3300 \text { ) }\end{array}$ & None & $\begin{array}{c}\text { 1/100 overnight at } \\
\text { 4degC (Sigma- } \\
\text { Aldrich L5264) }\end{array}$ & None & None \\
\hline $\begin{array}{l}\text { Terminal } \\
\text { deoxynucleotidyl } \\
\text { transferase dUTP } \\
\text { nick end labeling }\end{array}$ & \multicolumn{5}{|c|}{ DeadEnd Fluorometric TUNEL System (Promega G3250), per manufacturer's protocol } \\
\hline
\end{tabular}

was stained with $\mathrm{H \& E}$, and 10 to 12 images of granulomas were acquired for each sample. The rotator method for object volume estimation was then applied using the egg spine as the central reference point.

\section{Media and Intima Thickness Assessment}

Masked paraffin-embedded samples were immunofluorescence stained for $\alpha$-smooth muscle actin and throm- 
Table 3. Reagents for Immunostains on Human Tissue

\begin{tabular}{|c|c|c|c|c|c|}
\hline Immunostain & Antigen retrieval & Block & Primary antibody & Secondary antibody & Tertiary reagent \\
\hline p-Smad2/3 & $\begin{array}{l}\text { Citrate buffer } 30 \text { minutes in } \\
\text { steamer (Vector Laboratories } \\
\text { H-3300) }\end{array}$ & $\begin{array}{l}5 \% \text { Horse serum in } \\
\text { PBS } 1 \text { hour at } \\
\text { room temperature }\end{array}$ & $\begin{array}{l}\text { 1/2000 overnight at } 4^{\circ} \mathrm{C} \\
\text { (Cell Signaling } \\
\text { Technology } 3101 \text { ) }\end{array}$ & $\begin{array}{l}\text { 1/100 AF488 Donkey } \\
\text { anti-Rabbit (Invitrogen } \\
\text { A21206) } 1 \text { hour at } \\
\text { room temperature }\end{array}$ & None \\
\hline $\begin{array}{l}\alpha \text {-Smooth } \\
\text { muscle } \\
\text { actin }\end{array}$ & $\begin{array}{l}\text { Citrate buffer } 30 \text { minutes in } \\
\text { steamer (Vector Laboratories } \\
\text { H-3300) }\end{array}$ & $\begin{array}{l}5 \% \text { Goat serum in } \\
\text { PBS } 1 \text { hour at } \\
\text { room temperature }\end{array}$ & $\begin{array}{l}\text { 1/200 } 1 \text { hour at room } \\
\text { temperature } \\
\text { (DakoCytomation } \\
\text { M0851) }\end{array}$ & $\begin{array}{l}\text { 1/100 AF594 Goat anti- } \\
\text { mouse (Invitrogen } \\
\text { A11005) } 1 \text { hour at } \\
\text { room temperature }\end{array}$ & None \\
\hline CD31 & $\begin{array}{l}\text { Citrate buffer } 30 \text { minutes in } \\
\text { steamer (Vector Laboratories } \\
\text { H-3300) }\end{array}$ & $\begin{array}{l}1.5 \% \text { Rabbit serum } \\
\text { in PBS } 1 \text { hour at } \\
\text { room temperature }\end{array}$ & $\begin{array}{l}\text { 1:500 } 1 \text { hour at room } \\
\text { temperature (antibody } \\
\text { courtesy of Lee Lab, } \\
\text { Mayo Clinic) }\end{array}$ & $\begin{array}{l}\text { 1/100 Biotin-bound } \\
\text { rabbit anti-rat } \\
\text { (DakoCytomation } \\
\text { E0468) } 1 \text { hour at } \\
\text { room temperature }\end{array}$ & $\begin{array}{l}\text { Strepavidin-horseradish } \\
\text { peroxidase (Vector } \\
\text { Laboratories SA-5704), } \\
\text { then DAB } 5 \text { minutes, } \\
\text { then hematoxylin }\end{array}$ \\
\hline
\end{tabular}

bomodulin as described above to identify the smooth muscle cells and endothelial cells demarcating the media and intima, respectively. Twelve to 15 images of vessels at $\times 40$ magnification were randomly acquired from each sample. Image processing software (Image Pro Plus version 4.5.1; Media Cybernetics, Bethesda, MD) was used to identify the cross-sectional areas contained by the external perimeter of the media, the internal perimeter of the media, and the internal perimeter of the intima. A length:breadth ratio of less than 2 was required to ensure tranverse sections through the vessels. The radius $r_{i}$ for each of the three vessel layers $i$ enclosing an area $A_{i}$ was then calculated using the equation $r_{i}=\sqrt{A_{i} / \pi}$. The thicknesses of the media and intima were calculated as the differences between the respective radii, and expressed as a fraction of the external media radius.

\section{Cardiac Myocyte Stereologic and Planimetric Analysis}

Formalin-fixed and paraffin-embedded histological sections of mouse right ventricle tissue were stained as described above with tetramethylrhodamine isothiocyanate-labeled lectin from Bandeiraea simplicifolia to identify vascular structures and 4',6'-diamidino-2-phenylindole. Twelve to 15 images at $\times 40$ magnification were randomly captured of each sample. The component colors of the images were individually thresholded (Metamorph version 6.3; MDS Analytical Technologies, Sunnyvale, CA) to demarcate structures of interest (vessels and nuclei, respectively). Stereologic analysis was performed by projecting the thresholded images onto a grid of 216 points and counting the number of points intersecting with each tissue component.

\section{Human Tissue Immunostaining}

Immunohistochemistry and immunofluorescence staining on formalin-fixed and paraffin embedded samples of lung tissue obtained at autopsy from two patients who died of schistosomiasis-associated PAH in Brazil was performed using the reagents listed in the Table 3 .

\section{Statistics}

Analysis of variance was used to compare multiple groups (Kruskal-Wallis one-way analysis of variance on ranks for nonnormally distributed data), and the posthoc Tukey test (for normally distributed data) or the posthoc pairwise multiple comparison by Dunn's method (for nonnormally distributed data) was used to identify individual statistical differences within the groups. Graphs are presented as mean \pm SE, and statistical significance was taken as $P \leq 0.05$.

\section{Results}

Initially, we addressed whether PH can be experimentally induced by infecting mice with $S$. mansoni to reproduce the natural infection cycle in susceptible vertebrates, or through infusion of eggs directly into the venous circulation leading to embolization to the lungs. Although percutaneous cercarial infection, the normal route of infection, causes extensive portal and prehepatic disease, it leads to inconsistent shunting of eggs to the lungs. We found that percutaneous infection with cercariae alone or intravenous injection of schistosome eggs alone did not cause an increase in right ventricular pressure, suggesting each mode of infection appears incapable to incite $\mathrm{PH}$ in the mouse, ${ }^{15}$ but both sequential cercarial infection followed by intravenous egg challenge and i.p. sensitization with eggs followed by intravenous egg challenge resulted in an elevation in right ventricular pressure as compared with uninfected and unchallenged mice (Supplemental Figure 1, see http://ajp.amjpathol.org). We chose to further investigate the sequential cercariae and egg infection model as this disease process combines the normal route of infection with a reproducible egg burden in the lung.

Histological examination of wild-type, IL-13R $\alpha 1^{-/-}$, and IL-13R $\alpha 2^{-/-}$left lungs revealed no significant pulmonary vascular remodeling in uninfected and unchallenged mice, while infected wild-type mice developed a widespread arterial vasculopathy, often seen concurrently with a perivascular inflammatory cellular infiltrate (Figure 1A), particularly of $\mathrm{CD} 45^{+}$cells (Supplemental 
A

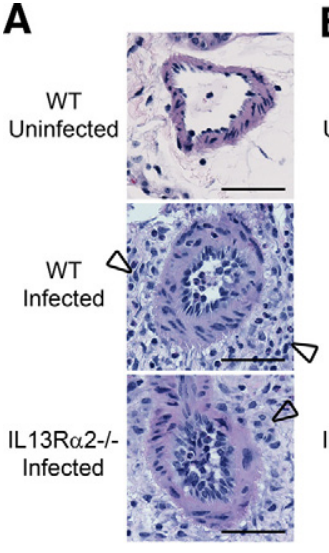

B

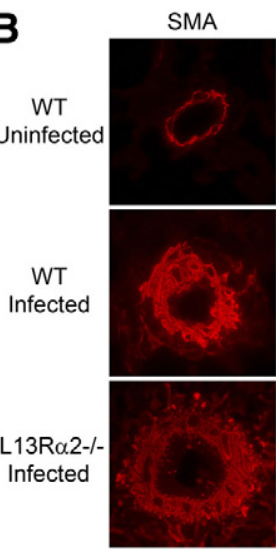

C

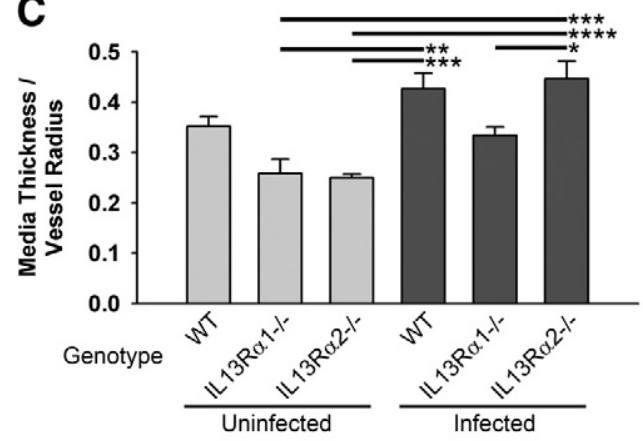

E

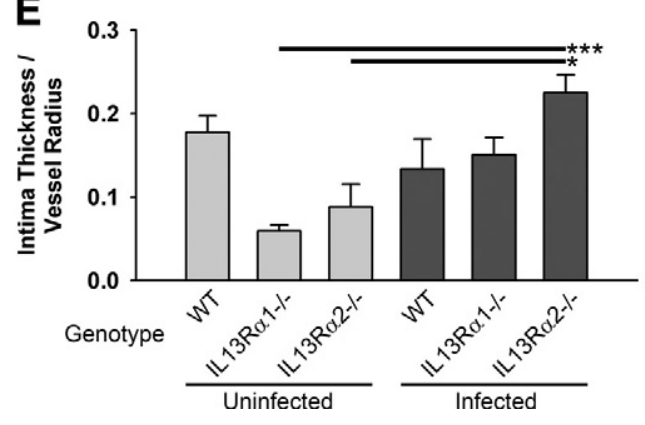

TM

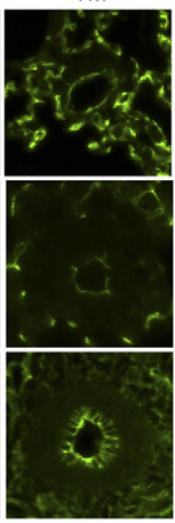

D

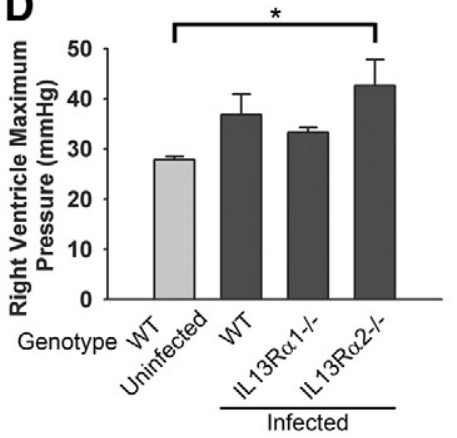

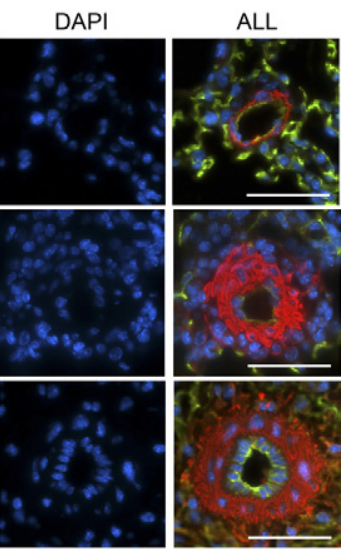
ing vascular intima (Scale bars: $50 \mu \mathrm{m}$ ). C: Quantification of vascular remodeling confirmed increased media thickness in the wild-type and IL-13R $\alpha 2^{-1-}$ infected mice (three to five animals per group; analysis of variance, $P<0.001$ for media comparison; for full posthoc analysis results see Supplemental Table 1 at http://ajp.amjpathol.org). D: Right ventricular catheterization demonstrated increased pressure in the infected groups (four to five animals per group; $P=$ 0.018 by Kruskal-Wallis one-way analysis of variance on ranks, ${ }^{*} P<0.005$ by posthoc pairwise multiple comparison by Dunn's method; for full posthoc analysis results see Supplemental Table 3 at http://ajp.amjpathol.org) E: Quantification of intima thickness demonstrated an increase only in the IL-13R $\alpha 2^{-/-}$infected mice (three to five animals per group; analysis of variance $P=0.003$; ${ }^{*} P<0.05,{ }^{* * *} P<0.01,{ }^{* * * *} P<0.005,{ }^{* * * * * * *} P<0.001$ by posthoc Tukey test for both media and intima analysis; for full posthoc analysis results see Supplemental Table 2 at http://ajp.amjpatbol.org).

Figure 1. Vascular remodeling and $\mathrm{PH}$ after $S$ mansoni infection. A: Arterial remodeling was inflammatory cell infiltrate (arrowheads; Scale bars: $50 \mu \mathrm{m})$. B: With $S$. mansoni infection, of wild-type (WT), IL-13R $\alpha 1^{-/-}$, and IL$13 \mathrm{R} \alpha 2^{-/-}$mouse lungs) and intimal (seen predominantly in IL-13R $\alpha 2^{-/-}$mouse lungs) layers was observed based on immunofluorescence for
Figure 2A, see http://ajp.amjpathol.org). Immunostaining for $\alpha$-smooth muscle actin and thrombomodulin highlighted marked pulmonary vascular remodeling involving the media and intima of pulmonary arteries (Figure 1B), whose endothelial lining remained one cell-thick, with no evidence of cell clustering as seen in plexiform lesions in humans. Quantification of the intimal and medial thickness in cross sections of pulmonary arteries showed that medial thickening accounted for the majority of the increase in vessel wall thickness, which was suppressed in mice lacking IL-13R $\alpha 1^{-/-}$(although not statistically significant compared with wild-type infected mice), while infection of mice with IL-13 gain-of-function signaling due to deletion of the IL-13R $\alpha 2^{-1-}$ led to a concurrent increase in intimal thickness (Figure 1, C and E, Supplemental Tables 1 and 2, see http://ajp.amjpathol.org). Quantification of the perivascular CD45 ${ }^{+}$profile density did not reveal any difference between the wild-type and IL-13 modulated mice (Supplemental Figure 2B, see http://ajp.amjpathol.org).
Right ventricular catheterization of a subset of mice, including control uninfected wild-type mice, revealed a 1.5-fold (43 versus $28 \mathrm{mmHg}$ ) increase in right ventricle maximum pressure in mice infected with $S$. mansoni, particularly in the IL-13R $\alpha 2^{-/-}$group when compared with the IL-13R $\alpha 1^{-1-}$ and wild-type mice (Figure 1D, Supplemental Table 3, see http://ajp.amjpathol.org). The magnitude of the rise in right ventricular pressures (indicative of pulmonary arterial pressures) is comparable to other mouse models of PAH (see Supplemental Table 4, see http://ajp.amjpathol.org). ${ }^{5,25-37}$ On average, the knockout groups of mice that developed more pronounced medial hypertrophy had concordantly greater right ventricular pressure; the correlation was however weaker when analyzed for individual animals $(P=0.11$; Supplemental Figure 3, see http://ajp.amjpathol.org). The right ventricular free-wall mass relative to the mass of the left ventricle (LV) and septum was increased in the IL-13R $\alpha 2^{-/-}$infected group alone (Figure 2, Supplemental Table S5, see http:// ajp. amjpathol.org), likely a result of remodeling due to the 


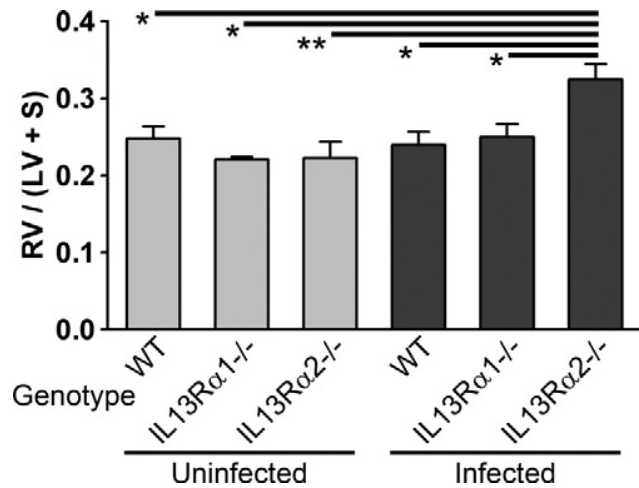

Figure 2. Right ventricular hypertrophy occurred in response to PH. Right ventricular mass relative to septum and left ventricular mass was increased in the infected IL-13R $\alpha 2^{-/-}$group (three to five animals per group; analysis of variance, $P=0.004 ;{ }^{*} P<0.05,{ }^{* *} P<0.01$ by posthoc Tukey test; for full posthoc analysis results, see Supplemental Table 5 at bttp://ajp.amjpatbol.org).

more severe $\mathrm{PH}$. Stereologic analysis of right ventricular blood vessel and nuclear density did not reveal significant differences between any of the infected groups (Supplemental Figure 4, see http://ajp.amjpathol.org).

The aforementioned differences in right ventricular pressures and pulmonary vascular remodeling among the groups of mice infected with schistosomiasis were probably not related to infection load or volumes of granulomas as the combination of cercariae and egg exposure resulted in a similar egg burden in the lungs of all infected wild-type and knockout for IL-13R $\alpha 1$ and $\alpha 2$ mice (Figure 3A). Moreover, there was no correlation between egg burden and right ventricular pressure $(P=$ 0.70; Supplemental Figure 5, see http://ajp.amjpathol. org). The volumes of the intraparenchymal peri-egg inflammatory granulomas did not differ among the different knockout mouse strains (Figure 3B), consistent with prior studies demonstrating similar schistosomiasis-induced granuloma volumes in the livers of mice lacking IL-13R $\alpha 1$ as compared with wild-type mice, ${ }^{17}$ and in mice lacking IL-13R $\alpha 2$ as compared with wild-type mice up to 8 weeks after infection. ${ }^{16}$
Our data indicate that the enhanced lung inflammatory response triggered by challenge with eggs in the setting of the natural infection correlates with the development of experimental schistosomiasis-associated $\mathrm{PH}$. Immunostaining revealed a heterogeneous population of cells within the granulomas, which might have contributed to the signaling cascade resulting in diffuse pulmonary vasculopathy (Figure 4). These cells included macrophages, eosinophils, and cells containing smooth muscle actin, which may represent either myofibroblasts and/or differentiated smooth muscle cells. The cells within the granulomas were undergoing significant proliferation in aggregate, with little evidence of apoptosis (Supplemental Figure 6A, see http://ajp.amjpathol.org), at least at the time point at which $\mathrm{PH}$ was documented (ie, 62 days after cercarial infection and 7 days after i.v. egg administration). The inflammatory cellular components of the granulomas were overall similar in the wild-type, IL-13R $\alpha 1^{-1-}$, and IL-13R $\alpha 2^{-1-}$ mice, with no significant differences in leukocyte (Supplemental Figure 6, see http://ajp.amjpathol. org) or macrophage density (Supplemental Figure 7, see http://ajp.amjpathol.org).

The increase in pulmonary pressures and pulmonary vascular remodeling observed in mice with enhanced IL-13 signaling might have involved increased expression of Th-2-dependent growth factors. The up-regulation of IL-13 expression in infected mice was confirmed with whole lung enzyme-linked immunosorbent assay (Supplemental Figure 8A, see http://ajp.amjpathol.org), with increased levels in wild-type, IL-13R $\alpha 1^{-1-}$, and IL$13 \mathrm{R} \alpha 2^{-1-}$ mice, and without significant differences within the pre- or postinfection groups (wild-type, IL-13R $\alpha 1^{-/-}$, and IL-13R $\alpha 2^{-/-}$mice).

Recent evidence has identified the FIZZ family of mediators as significant regulators of liver fibrosis and pulmonary inflammation due to experimental schistosomiasis $^{18}$ as well as in hypoxia-induced $\mathrm{PH}^{38}$ Immunostaining for RELM- $\alpha$, a downstream target of IL-4 and IL-13, demonstrated significant expression around the granulomas but not the blood vessels of infected mice (Figure 5A).
A

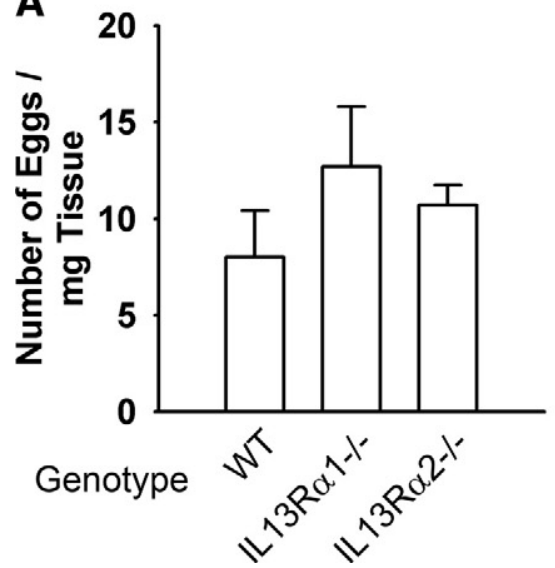

B

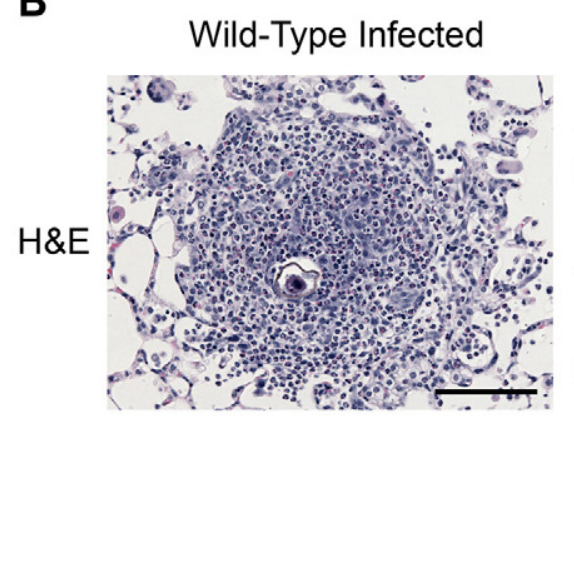

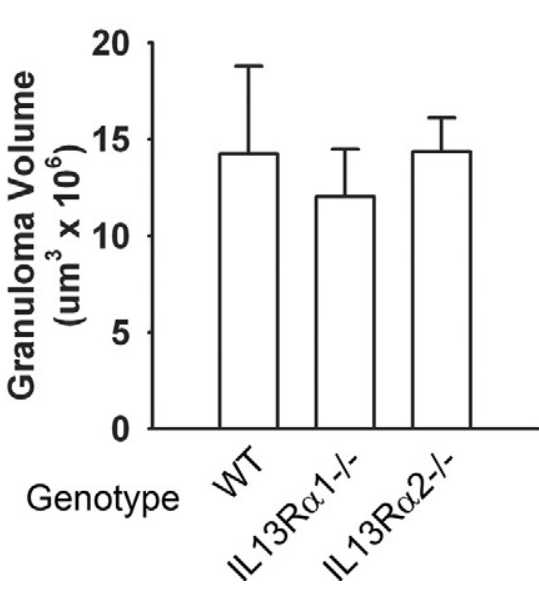

Figure 3. Similar egg burden and granuloma volumes after $S$. mansoni infection. A: Mean egg burden for each model after cercarial and egg infection as determined by KOH digest (five animals per group; $P=0.39$ by analysis of variance). B: Intraparenchymal peri-egg granulomas were present in the infected mice (representative H\&E stained lungs; left panel; Scale bar: $100 \mu \mathrm{m}$ ). The granuloma volumes were similar in all genetic models as determined by the rotator method (five animals per group; $P=0.85$ by analysis of variance). 
$\alpha \mathrm{SM}$-actin
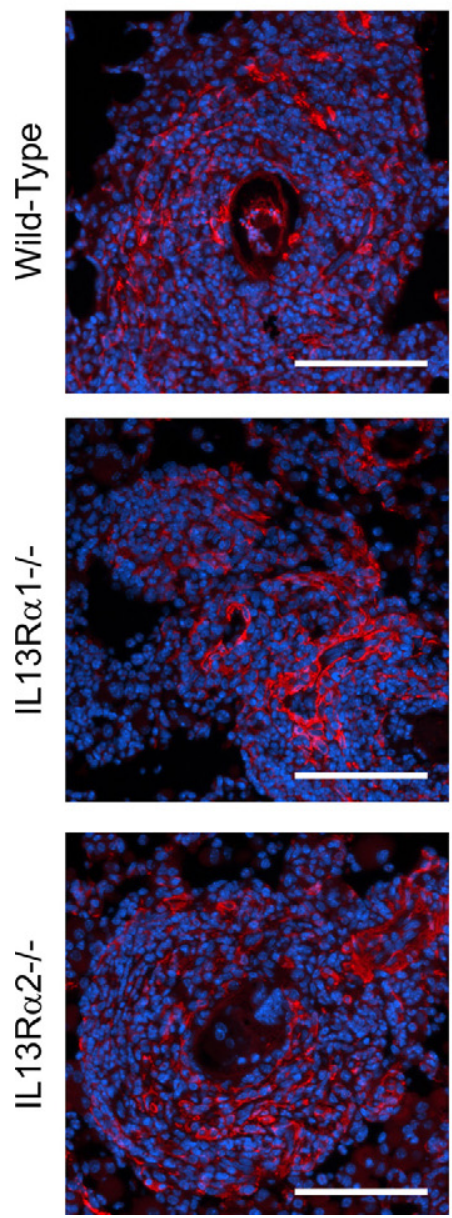

MAC-3
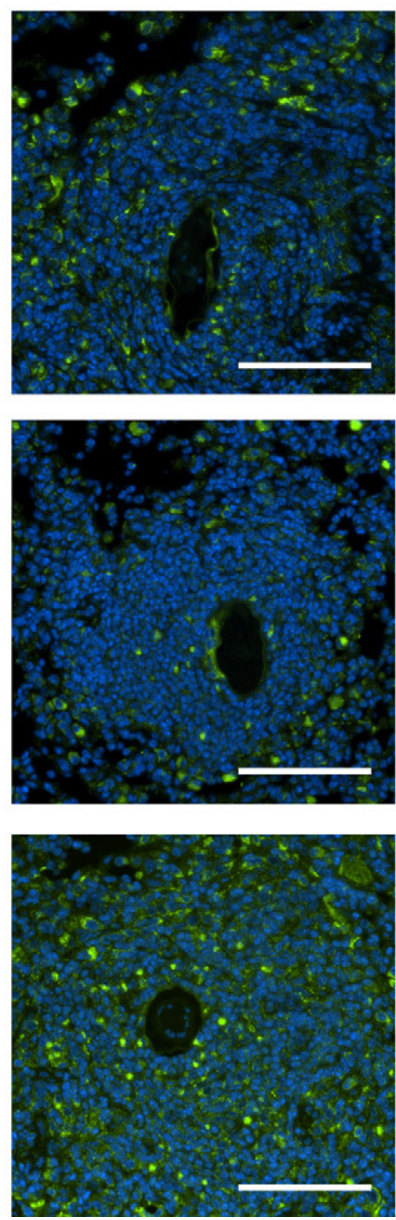

MBP
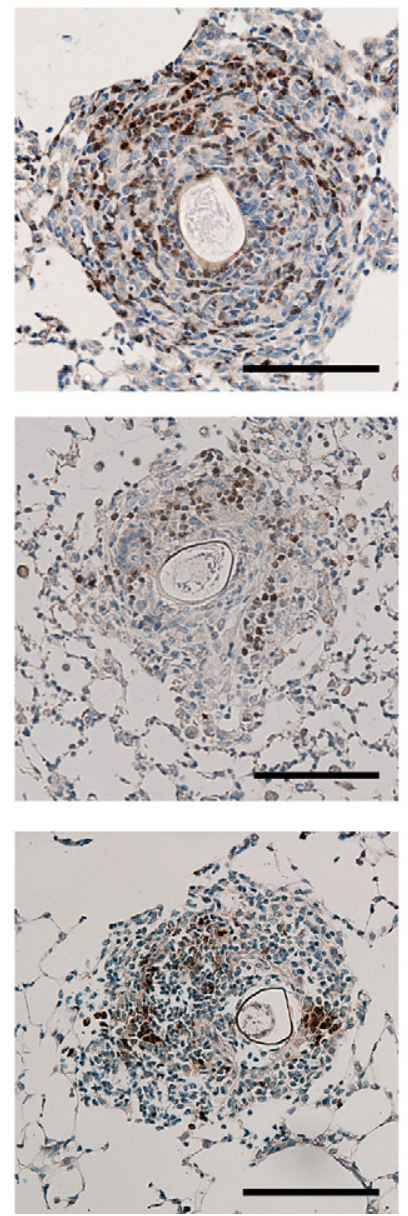

PCNA
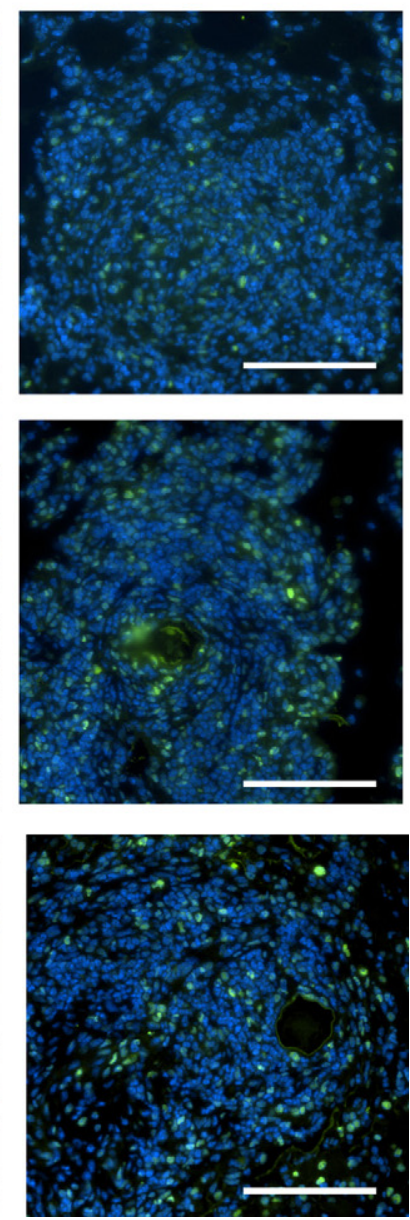

Figure 4. Vascular and inflammatory cell composition and evidence of cell proliferation in pulmonary peri-egg granulomas in infected mice. Granulomas in wild-type (upper panels), IL-13R $\alpha 1^{-/-}$(middle panels), and IL-13R $\alpha 2^{-/-}$(lower panels) infected mice are composed of smooth muscle cells or myofibroblasts ( $\alpha$ SM-actin, $\alpha$-smooth muscle actin), macrophages (MAC-3) and eosinophils (MBP, major basic protein). Considerable proliferation was also detected (PCNA, proliferating cell nuclear antigen) (Scale bars: $100 \mu \mathrm{m}$ ).

Lungs of IL-13R $\alpha 1$ knockout mice showed suppressed RELM- $\alpha$ expression, which was confirmed by immunoblotting (Figure 5B). These data correlate with susceptibility to schistosomiasis-associated $\mathrm{PH}$ and vascular remodeling as compared with the uninfected mice or infected IL-13R $\alpha 1^{-1-}$ mice. Surprisingly, the expression level of RELM- $\alpha$ was lower in the infected IL-13R $\alpha 2^{-1-}$ mice compared with wild-type infected mice by densitometric analysis of western blots. This finding suggests that IL-13/RELM- $\alpha$ may interface with other pathways involved in pulmonary vascular remodeling.

Serum TNF- $\alpha$ levels are elevated in patients with $S$. mansoni infection ${ }^{39}$ and correlate with more severe disease. ${ }^{40}$ Furthermore, TNF- $\alpha$ overexpression is associated with $\mathrm{PH},{ }^{41}$ although TNF- $\alpha$ blockade may not suppress experimental PH. ${ }^{42}$ Measurement of TNF- $\alpha$ in whole lung lysates in S. mansoni infected and uninfected wild-type, IL-13R $\alpha 1^{-1-}$, and IL-13R $\alpha 2^{-/-}$mice revealed an increased level in only the wild-type infected mice compared with all other groups (Supplemental Figure 8C, see http://ajp.amjpathol.org). We furthermore investigated p44/42 mitogen-activated protein kinase (MAPK) (extra- cellular signal-regulated kinase 1/2), downstream targets of TNF- $\alpha \cdot{ }^{43}$ Activity of $p 44 / 42$ MAPK levels was increased in IL-13R $\alpha 1^{-1-}$ and IL-13R $\alpha 2^{-1-}$ mice compared with wild-type mice, but no significant changes were detected with schistosomiasis infection (Supplemental Figure 9, see $h$ ttp://ajp.amjpathol.org).

Altered TGF- $\beta$ signaling has also been linked to the vascular pathology of $\mathrm{PH}^{44}$ with evidence that $\mathrm{PH}$ smooth muscle cells proliferate with TGF- $\beta^{45}$ and expression of phosphorylated Smad2/3 ( $p-S m a d 2 / 3$; the active form) are increased in remodeled pulmonary arteries. ${ }^{3}$ Lungs of schistosomiasis-infected mice showed a significantly increased expression of $\mathrm{p}$-Smad2/3 present in both granulomas and pulmonary arteries in the infected animals (Figure 5C). Immunoblots of phosphorylated and total Smad2/3 showed up-regulation of both phosphorylated and total Smad2 (little Smad3 signal was seen) in the infected mice, with the highest signal in IL-13R $\alpha 2^{-/-}$ infected lungs (Figure 5D). The band representing expression of Smad2 was confirmed by a parallel Western blot analysis (Supplemental Figure 10, see http://ajp. amjpathol.org). The absolute levels of TGF- $\beta$ were not 
A

\section{RELM- $\alpha$}
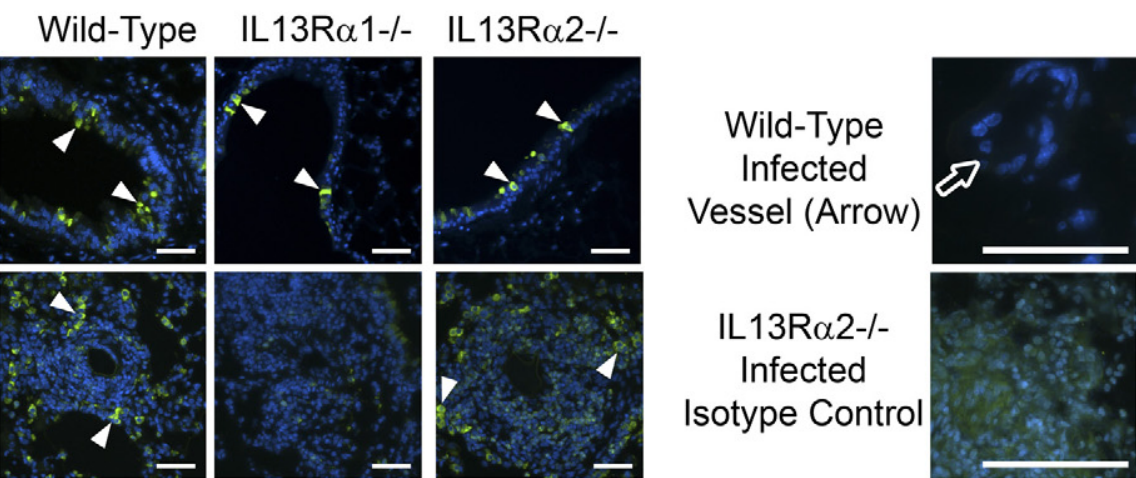

B
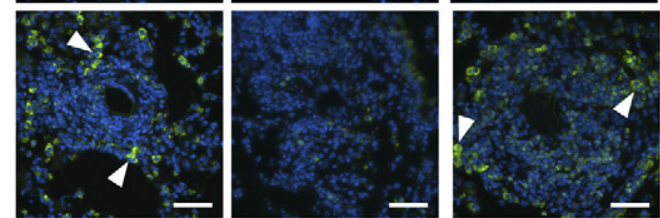

13R $\alpha 2-/-$ Infected

RELM- $\alpha$ / $\beta$-actin Average Densitometry

RELM- $\alpha$ (14kDa)

$\beta$-actin (49kDa)

Genotype

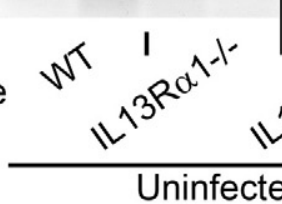

C

\section{p-Smad2/3}
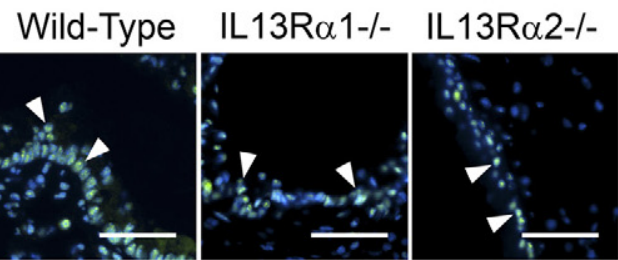

1.00

0.60

Uninfected
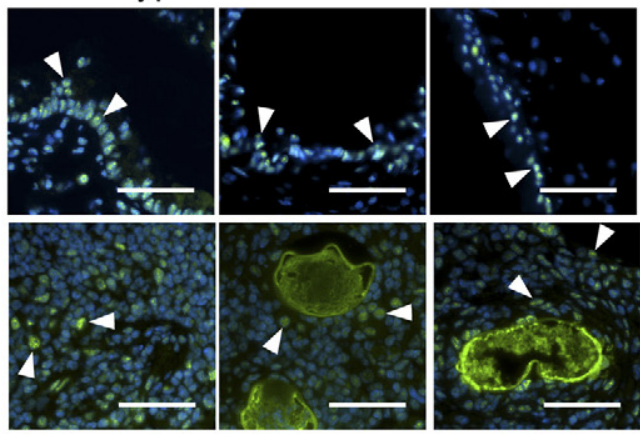

Wild-Type

Infected

Vessel (Arrow)

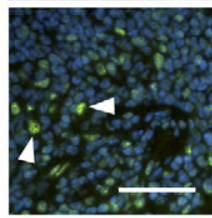

\section{IL13R $\alpha 2-/-$}

Infected

Isotype Control

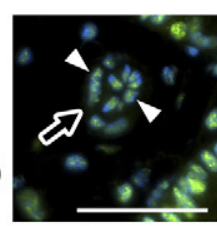

D p-Smad2/3/Total Smad2/3

Average Densitometry

p-Smad2/3 (61kDa)

Smad2/3 $(61 \mathrm{kDa})$

TGF- $\beta$ Precursor $(61 \mathrm{kDa})$

TGF- $\beta$ Monomer (11kDa)

$\beta$-actin (49kDa)

\subsection{0}

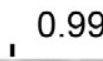

\subsection{6}

1.78

1.82

3.40

Genotype

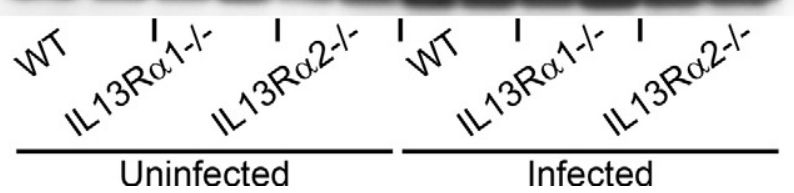

Figure 5. RELM- $\alpha$ and p-Smad 2 are up-regulated in response to $S$. mansoni infection. A: RELM- $\alpha$, a downstream target of IL- 4 and IL- 13 signaling, was expressed in pulmonary peri-egg granulomas in infected mice, but suppressed in the absence of IL-13R $\alpha 1$, as demonstrated by immunostaining (arrowheads mark positive cells) and immunoblot (B; densitometry: five animals per group). There was no evidence of pulmonary intravascular RELM- $\alpha$ expression (representative vessel from wild-type infected animal shown). (The full Western blot is shown in Supplemental Figure 13, see http://ajp.amjpathol.org). C: p-Smad2/3 activity, a downstream target of TGF- $\beta$ signaling, is increased in both granulomas and vessels with $S$. mansoni infection (arrowheads mark positive cells), and quantified by immunoblot normalized by total SMAD2 (D; densitometry: three to five animals per group; $P=0.44$ by analysis of variance). Only bands for Smad2 ( $61 \mathrm{kDa})$ were seen (Scale bars are $50 \mu \mathrm{m}$.) 
A
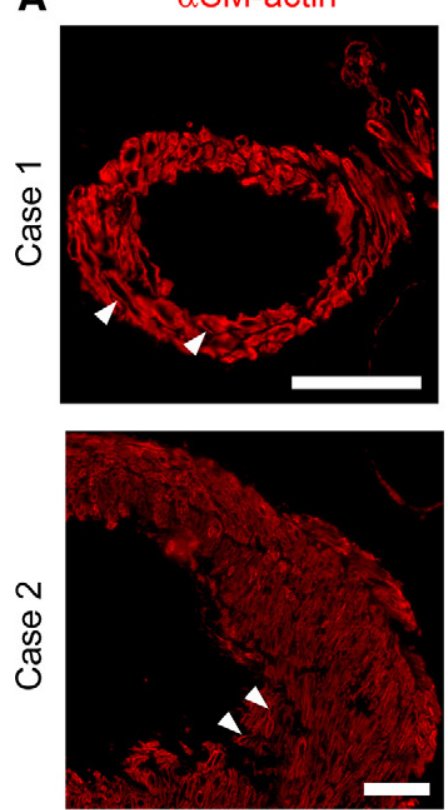

B
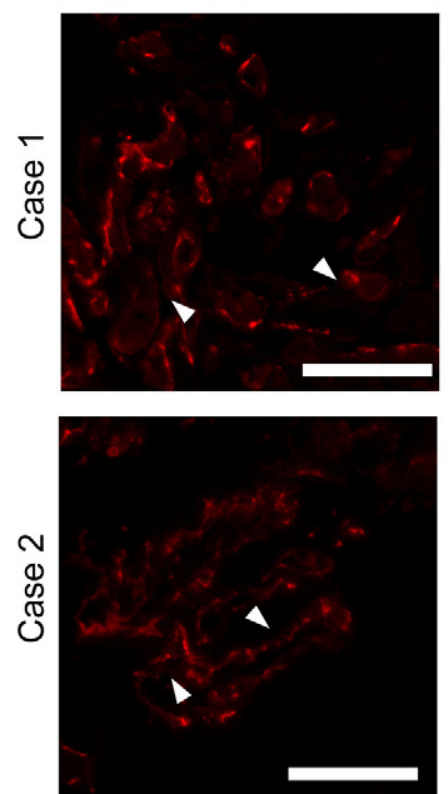

$\mathrm{p}-\mathrm{Smad} 2 / 3$
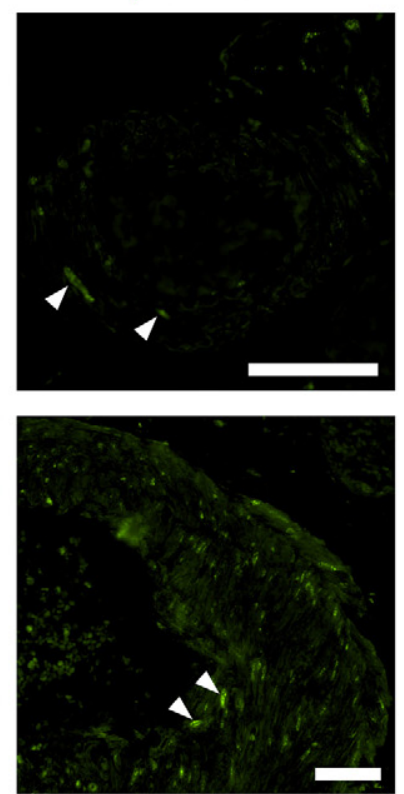

p-Smad $2 / 3$
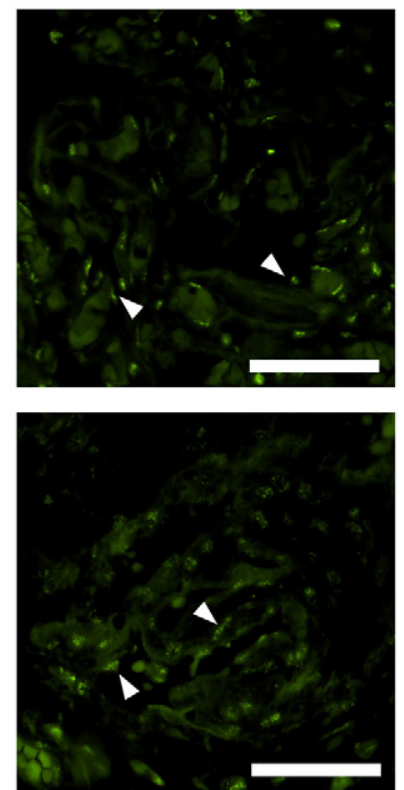

DAPI
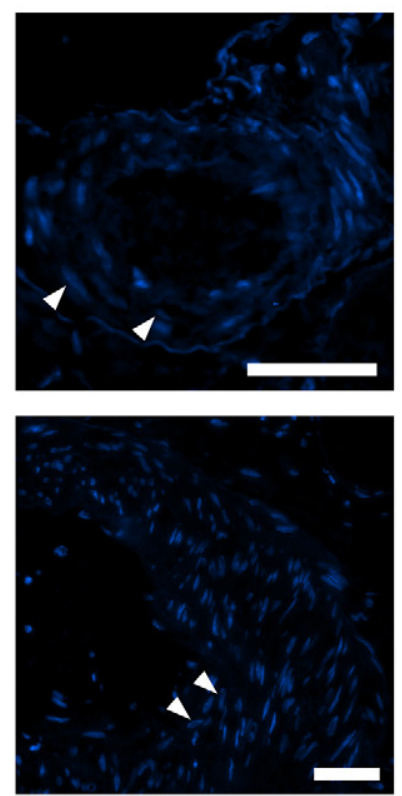

DAPI
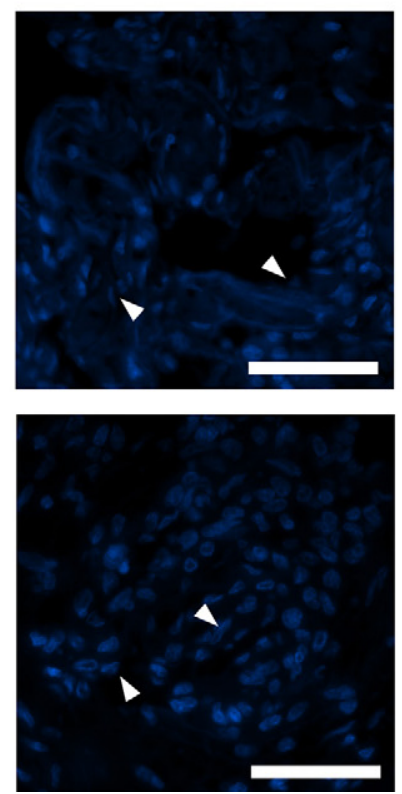

All
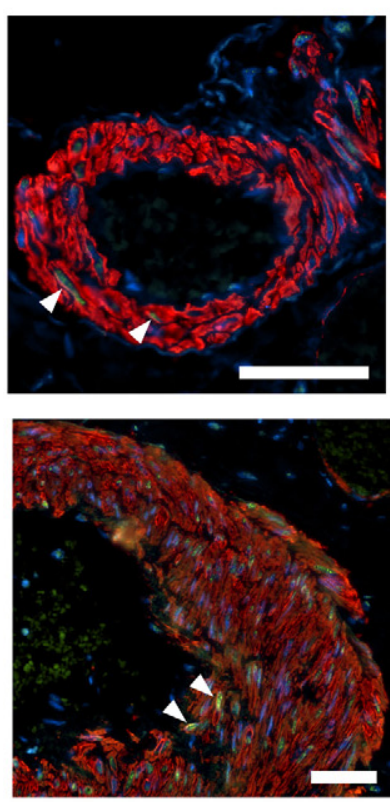

All
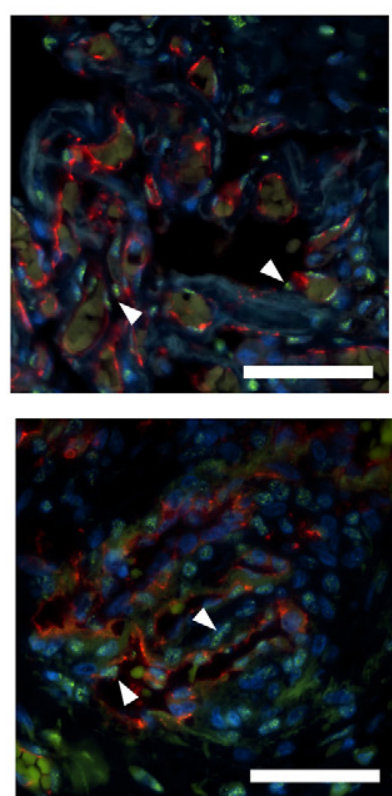

Figure 6. p-Smad2/3 signaling is present in vascular lesions of patients who died of schistosomiasis-associated PAH. Tissue from two patients was immunostained. A: Costaining for $\alpha$-smooth muscle actin ( $\alpha$ SM-actin) and p-Smad2/3 reveals nuclear activity in the media of vessels with thickened media (arrowheads mark representative positive cells). B: Costaining for CD31 and p-Smad2/3 reveals nuclear activity in many cells present within plexiform lesions (arrowheads mark representative positive cells) (Scale bars: $50 \mu \mathrm{m}$.)

altered in infected mice as assessed by Western blot (for both the precursor of TGF- $\beta$ and TGF- $\beta$ monomers) and whole-lung enzyme-linked immunosorbent assay (for TGF- $\beta$; Supplemental Figure 8A, see at http://ajp. amjpathol.org).

We then sought to determine whether the findings of altered vascular TGF- $\beta$ signaling in our animal model might extend to humans by looking for evidence of p-Smad2/3 up-regulation in human tissue, using specimens obtained at autopsy from two patients who died of schistosomiasis-associated $\mathrm{PH}$ in Brazil. Costaining the pulmonary tissue for $\mathrm{p}$-Smad2/3 and $\alpha$-smooth muscle actin revealed significant $\mathrm{p}-\mathrm{Smad} 2 / 3$ activity in the smooth muscle cells of vessels with thickened media (Figure 6A), and co-staining for p-Smad2/3 and CD31 revealed significant $\mathrm{p}-\mathrm{Smad} 2 / 3$ activity in vascular channels within the plexiform lesions (Figure 6B). Significant p-Smad2/3 signal was absent in the media of vessels from a human control specimen (an unsuccessful lung donor, with no known pulmonary pathology), although there was $\mathrm{p}-\mathrm{Smad} 2 / 3$ activity in the normal pulmonary parenchyma (Supplemental Figure 11, see http://ajp. 
amjpathol.org). These results are consistent with our prior observations of idiopathic PAH lungs using p-Smad2 alone. ${ }^{3}$ Specificity of the p-Smad2/3 antibody used was confirmed by positive signal in wild-type mouse cartilage (positive control) and absent signal in K5CrePR.Smad2 $\mathrm{fl} / \mathrm{fl} . \mathrm{Smad} 3^{-1-}$ mouse dermis (negative control; Supplemental Figure 12, see http://ajp.amjpathol.org).

\section{Discussion}

Our study presents evidence of experimental pulmonary arterial remodeling and $\mathrm{PH}$ in mice infected by Schistosoma mansoni. Our results indicated that the combination of percutaneous cercariae infection and augmentation by i.v. egg injection is required for the development of vascular remodeling and $\mathrm{PH}$, which was significant in mice with concurrent up-regulation in IL-13 signaling from deletion of IL-13R $\alpha 2$.

Disease progression in human schistosomiasis infection includes portal hypertension and porto-systemic shunting, which may be a prerequisite for the development of $\mathrm{PH}$. Furthermore, chronic hepatitis and liver cirrhosis have also been linked to severe PAH. However, our finding that i.p. sensitization before intravenous egg administration also caused $\mathrm{PH}$ highlighted the potential requirement of a more robust pulmonary perivascular inflammatory response and inflammatory cell infiltrate rather than the need for hepatic disease. Injection of a similar quantity of intravenous eggs alone did not cause right ventricular hypertension, suggesting that embolic disease alone does not cause experimental PH. Moreover, percutaneous infection with cercariae but without egg augmentation does not result in $\mathrm{PH}$, which was also reported by a recent study, ${ }^{15}$ and further strengthens the hypothesis that hepatic fibrotic disease does not suffice to cause $\mathrm{PH}$. Mice with only cercarial infection do have some degree of egg shunting to the lungs, but the burden is quite heterogeneous in acute infection and may not be adequate to cause extensive pulmonary disease resulting in physiological change.

Similar to prior publications centered on the liver disease and pulmonary inflammation, ${ }^{15}$ we found evidence suggesting IL-13 signaling is an important mediator of the granulomatous and vascular response to schistosomiasis infection. Up-regulation of signaling in the IL-13 pathway occurred in the wild-type infected mice, specifically associated with RELM- $\alpha$ expression. In a distinct mouse model of Th-2-driven inflammation, inhaled aspergillus also resulted in RELM- $\alpha$ up-regulation and vascular remodeling with no evidence of chronic $\mathrm{PH}$, yet mild increases in right ventricular pressures were revealed only when sensitized lungs were challenged with acute hypoxia. ${ }^{25}$

Our finding of $\mathrm{PH}$ in S. mansoni-infected mice lacking IL-13Ra2 suggests that enhanced IL-13 signaling is sufficient to cause $\mathrm{PH}$ in this model. This up-regulation occurred in the absence of a significant increase in total lung IL-13 levels as compared with wild-type mice with a less pronounced phenotype. Prior studies of schistosomiasis inflammation in the liver have demonstrated the exacerbated response in IL-13R $\alpha 2^{-1-}$ mice is due to increased signaling mediated by $\mid \mathrm{L}-13 \mathrm{R} \alpha 1$, as treating the mice with soluble IL-13R $\alpha 2-\mathrm{Fc}$ to block the effects of $\mathrm{IL}-13$ results in reversal of the phenotype. ${ }^{46}$

We also detected an increase in RELM- $\alpha$ signaling in schistosomiasis-infected mice, which might contribute to the vascular response in this model of $\mathrm{PH}$. Previous studies have found RELM- $\alpha$ to be necessary for $\mathrm{PH}$ in the rat chronic hypoxia model and, when overexpressed, RELM- $\alpha$ increases pulmonary artery pressures in otherwise healthy rats in the absence of hypoxia. ${ }^{38}$ However, the increased $\mathrm{PH}$ phenotype in IL-13R $\alpha 2^{-1-}$ mice was not associated with a further increase in RELM- $\alpha$, suggesting interactions between IL-13/RELM- $\alpha$ and other pathways contributory to pulmonary vascular remodeling.

Here, we found suppression of IL-13 signaling by knocking out IL-13R $\alpha 1$ resulted in less vascular remodeling and $\mathrm{PH}$ (although not statistically significant), associated with near-complete suppression of RELM- $\alpha$ signaling. This observation suggests that $\mathrm{IL}-13$ signaling may be necessary for vascular remodeling after $S$. mansoni infection. However, demonstration of this hypothesis would likely require either knocking out IL-13 or suppression of IL-13 with a small molecule inhibitor or biologicals in vivo.

The observations of pulmonary vascular remodeling in wild-type, IL-13R $\alpha 1^{-/-}$, and IL-13R $\alpha 2^{-/-}$models provides complementary insights into the role of IL-13 signaling in this experimental model of $\mathrm{PH}$. The finding of similar size and composition of the inflammatory peri-ova granulomas, peri-vascular inflammation, and vascular remodeling in our $\mathrm{IL}-13 \mathrm{R} \alpha 1^{-1-}$ and wild-type mice suggests IL-13 may not be required for pulmonary vascular remodeling, although a prior study blocking IL-13 demonstrated smaller granulomas. ${ }^{47}$ Non-IL-13-dependent mechanisms, such as TGF- $\beta$ or IL-4, may contribute to the pulmonary vascular remodeling process. We have found evidence of TGF- $\beta$ signaling up-regulation in both the mouse and human lungs, and blocking TGF- $\beta$ is protective against experimental monocrotaline-induced $\mathrm{PH} .{ }^{6}$ Schistosoma-infected IL-13R $\alpha 1^{-1-}$ mice as compared with wild-type mice have an increase in $\mathrm{CD} 4^{+} \mathrm{T}$ cells producing IL-4, ${ }^{17}$ and IL-13 blockade in IL-4-deficient mice resulted in near-complete abrogation of granuloma formation. ${ }^{47}$ Furthermore, the enhanced pulmonary vascular remodeling phenotype in $S$. mansoni infected IL-13R $\alpha 2^{-I-}$ mice could be due to a) increased IL-13 signaling or b) alteration of non-IL-13 cellular signaling caused by the lack of this receptor. ${ }^{48}$ Clarification of the roles of IL-13 versus non-IL-13 signaling are presently being addressed by approaches to directly block IL-13 in IL-13R $\alpha 2^{-1-}$ mice, experiments which are currently ongoing.

We also investigated the potential roles of TNF- $\alpha$ and p42/44 MAPK in our model of experimental PH and found TNF- $\alpha$ to be elevated in wild-type infected mice only. Given the absence of a clear correlation between TNF- $\alpha$ and severity of vascular remodeling and $\mathrm{PH}$, the significance of TNF- $\alpha$ signaling in this experimental model of $S$. mansoni associated $\mathrm{PH}$ is unclear and may not be directly contributory. We also observed elevations in 
p42/44 MAPK in IL-13R $\alpha 1^{-/-}$and IL-13R $\alpha 2^{-/-}$mice compared with wild-type mice, independent of $S$. mansoni infection, and thus the contribution of p42/44 MAPK to $\mathrm{PH}$ in this model is unclear. Indeed, prior studies have shown increased expression of p42/44 MAPK in rats exposed to chronic hypoxia, ${ }^{49}$ but which may not be necessary for the hypertensive response. ${ }^{50}$

Abnormal TGF- $\beta$ family signaling has been linked to human and experimental PAH. ${ }^{3,6}$ We found up-regulation of the TGF- $\beta$ signaling pathway manifest by increased Smad2/3 phosphorylation in areas of vascular remodeling in both the mouse model and human tissue from subjects who died from schistosomiasis-associated $\mathrm{PH}$. The absence of an increase in total TGF- $\beta$ levels despite an increase in downstream signaling is similar to prior findings in experimental chronic hypoxia-induced $\mathrm{PH}^{51}$ The contribution of TGF- $\beta$ signaling in schistosomiasisinduced PH may be in conjunction with IL-13 signaling, as $\mathrm{IL}-13$ has previously been shown to stimulate and activate TGF- $\beta .^{52}$ Although TGF- $\beta$ expression is also upregulated in the murine liver after schistosomiasis infection, neutralizing TGF- $\beta$ activity by treating mice with an antagonistic antibody to TGF- $\beta$ failed to modulate the anti-egg granulomatous response. ${ }^{53}$ Potential differences between the hepatic fibrotic response and pulmonary vascular remodeling may be elucidated by future targeting of TGF- $\beta$ in this PH model.

In summary, infecting mice with $S$. mansoni cercariae percutaneously and then augmenting the pulmonary disease by intravenous egg administration resulted in pulmonary arterial vascular remodeling and $\mathrm{PH}$, particularly in mice lacking the competitive "decoy" IL-13 receptor, IL-13R $\alpha 2$. Up-regulation of IL-13 and RELM- $\alpha$, a target of IL-13 signaling, in infected mice also supports the role of IL-13 in the pathogenesis of schistosomiasis-associated $\mathrm{PH}$. The parallel histology, physiology, and cytokine signaling in both the mouse and human disease highlights the potential relevance of the animal model as an experimental platform for future studies of schistosomiasis-induced $\mathrm{PH}$.

\section{Acknowledgments}

We thank Drew Murphy (Regeneron Pharmaceuticals) for providing breeding pairs of IL-13R $\alpha 1^{-1-}$ mice; Marion Kasaian (Wyeth Research) for breeding pairs of IL$13 R \alpha 2^{-I-}$ mice; Nancy and James Lee (Mayo Clinic, Scottsdale AZ) for the rat anti-major basic protein antibody; and Gangwen Han, Stephen Malkoski, and Masako Oka (University of Colorado) for providing tissue samples from K5CrePR.Smad2 fl/fl.Smad3 ${ }^{-/-}$mice.

\section{References}

1. Tuder RM, Marecki JC, Richter A, Fijalkowska I, Flores S: Pathology of pulmonary hypertension. Clin Chest Med 2007, 28:23-42, vii

2. Cool CD, Rai MD, Yeager ME, Hernandez-Saavedra D, Serls AE, Bull TM, Geraci MW, Brown KK, Routes JM, Tuder RM, Voelkel NF: Expression of human herpesvirus 8 in primary pulmonary hypertension. N Engl J Med 2003, 349:1113-1122
3. Richter A, Yeager ME, Zaiman A, Cool CD, Voelkel NF, Tuder RM: Impaired transforming growth factor- $\beta$ signaling in idiopathic pulmonary arterial hypertension. Am J Respir Crit Care Med 2004 Dec 15, 170:1340-1348

4. Schermuly RT, Dony E, Ghofrani HA, Pullamsetti S, Savai R, Roth M Sydykov A, Lai YJ, Weissmann N, Seeger W, Grimminger F: Reversal of experimental pulmonary hypertension by PDGF inhibition. J Clin Invest 2005, 115:2811-2821

5. Li X, Zhang X, Leathers R, Makino A, Huang C, Parsa P, Macias J, Yuan JX, Jamieson SW, Thistlethwaite PA: Notch3 signaling promotes the development of pulmonary arterial hypertension. Nat Med 2009, 15:1289-1297

6. Zaiman AL, Podowski M, Medicherla S, Gordy K, Xu F, Zhen L, Shimoda LA, Neptune E, Higgins L, Murphy A, Chakravarty S, Protter A, Sehgal PB, Champion HC, Tuder RM: Role of the TGF- $\beta /$ Alk5 signaling pathway in monocrotaline-induced pulmonary hypertension. Am J Respir Crit Care Med 2008, 177:896-905

7. Bonnet S, Michelakis ED, Porter CJ, ndrade-Navarro MA, Thebaud B, Bonnet S, Haromy A, Harry G, Moudgil R, McMurtry S, Weir EK, Archer SL: An abnormal mitochondrial-hypoxia inducible factor$1 \alpha-K v$ channel pathway disrupts oxygen sensing and triggers pulmonary arterial hypertension in fawn hooded rats: similarities to human pulmonary arterial hypertension. Circulation 2006, 113:2630-2641

8. Fijalkowska I, Xu W, Comhair SA, Janocha AJ, Mavrakis LA, Krishnamachary B, Zhen L, Mao T, Richter A, Erzurum SC, Tuder RM: Hypoxia inducible-factor1alpha regulates the metabolic shift of pulmonary hypertensive endothelial cells. Am J Pathol 2010, 176: $1130-1138$

9. Butrous G, Ghofrani HA, Grimminger F: Pulmonary vascular disease in the developing world. Circulation 2008 Oct 21, 118:1758-1766

10. Andrade ZA: Schistosomiasis and liver fibrosis. Parasite Immunol 2009, 31:656-663

11. Lapa M, Dias B, Jardim C, Fernandes CJ, Dourado PM, Figueiredo M, Farias A, Tsutsui J, Terra-Filho M, Humbert M, Souza R: Cardiopulmonary manifestations of hepatosplenic schistosomiasis. Circulation 2009, 119:1518-1523

12. Burke ML, Jones MK, Gobert GN, Li YS, Ellis MK, McManus DP Immunopathogenesis of human schistosomiasis. Parasite Immunol 2009, 1931:163-176

13. Marecki JC, Cool CD, Parr JE, Beckey VE, Luciw PA, Tarantal AF, Carville A, Shannon RP, Cota-Gomez A, Tuder RM, Voelkel NF, Flores SC: HIV-1 Nef is associated with complex pulmonary vascular lesions in SHIV-nef-infected macaques. Am J Respir Crit Care Med 2006, 174:437-445

14. Tuder RM: Pathology of pulmonary arterial hypertension. Semin Respir Crit Care Med 2009, 1930:376-385

15. Crosby A, Jones FM, Southwood M, Stewart S, Schermuly R, Butrous G, Dunne DW, Morrell NW: Pulmonary vascular remodeling correlates with lung eggs and cytokines in murine schistosomiasis. Am J Respir Crit Care Med 2010, 181:279-288

16. Mentink-Kane MM, Cheever AW, Thompson RW, Hari DM, Kabatereine NB, Vennervald BJ, Ouma JH, Mwatha JK, Jones FM, Donaldson DD, Grusby MJ, Dunne DW, Wynn TA: IL-13 receptor $\alpha 2$ downmodulates granulomatous inflammation and prolongs host survival in schistosomiasis. Proc Natl Acad Sci USA 2004, 101:586-590

17. Ramalingam TR, Pesce JT, Sheikh F, Cheever AW, Mentink-Kane MM, Wilson MS, Stevens S, Valenzuela DM, Murphy AJ, Yancopoulos GD, Urban JF, Jr., Donnelly RP, Wynn TA: Unique functions of the type II interleukin 4 receptor identified in mice lacking the interleukin 13 receptor $\alpha 1$ chain. Nat Immunol 2008, 9:25-33

18. Pesce JT, Ramalingam TR, Wilson MS, Mentink-Kane MM, Thompson RW, Cheever AW, Urban JF, Wynn TA: Retnla (relm $\alpha / f i z z 1)$ suppresses helminth-induced Th2-type immunity. PLoS Pathog 2009, 2005:e1000393

19. Dorfmuller P, Perros F, Balabanian K, Humbert M: Inflammation in pulmonary arterial hypertension. Eur Respir J 2003, 1922:358-363

20. Wood N, Whitters MJ, Jacobson BA, Witek J, Sypek JP, Kasaian M, Eppihimer MJ, Unger M, Tanaka T, Goldman SJ, Collins M, Donaldson DD, Grusby MJ: Enhanced interleukin (IL)-13 responses in mice lacking IL-13 receptor $\alpha 2$. J Exp Med 2003, 197:703-709

21. Boros DL: The role of cytokines in the formation of the schistosome egg granuloma. Immunobiology 1994, 191:441-450

22. Hemnes AR, Zaiman A, Champion HC: PDE5A inhibition attenuates bleomycin-induced pulmonary fibrosis and pulmonary hypertension 
through inhibition of ROS generation and RhoA/Rho kinase activation. Am J Physiol Lung Cell Mol Physiol 2008, 294:L24-L33

23. Cheever AW: Conditions affecting the accuracy of potassium hydroxide digestion techniques for counting Schistosoma mansoni eggs in tissues. Bull World Health Organ 1968, 39:328-331

24. Tandrup T, Gundersen HJ, Jensen EB: The optical rotator. J Microsc 1997, 186:108-120

25. Dumitrascu R, Koebrich S, Dony E, Weissmann N, Savai R, Pullamsetti SS, Ghofrani HA, Samidurai A, Traupe H, Seeger W, Grimminger F, Schermuly RT: Characterization of a murine model of monocrotaline pyrrole-induced acute lung injury. BMC Pulm Med 2008, 8:25

26. Daley E, Emson C, Guignabert C, de Waal MR, Louten J, Kurup VP, Hogaboam C, Taraseviciene-Stewart L, Voelkel NF, Rabinovitch M, Grunig E, Grunig G: Pulmonary arterial remodeling induced by a Th2 immune response. J Exp Med 2008, 205:361-372

27. Launay JM, Herve P, Peoc'h K, Tournois C, Callebert J, Nebigil CG, Etienne N, Drouet L, Humbert M, Simonneau G, Maroteaux L: Function of the serotonin 5-hydroxytryptamine $2 \mathrm{~B}$ receptor in pulmonary hypertension. Nat Med 2002, 8:1129-1135

28. Long L, MacLean MR, Jeffery TK, Morecroft I, Yang X, Rudarakanchana N. Southwood M, James V, Trembath RC, Morrell NW: Serotonin increases susceptibility to pulmonary hypertension in BMPR2deficient mice. Circ Res 2006, 98:818-827

29. Song Y, Jones JE, Beppu H, Keaney JF, Jr., Loscalzo J, Zhang YY: Increased susceptibility to pulmonary hypertension in heterozygous BMPR2-mutant mice. Circulation 2005, 112:553-562

30. Fredenburgh LE, Ma J, Perrella MA: Cyclooxygenase-2 inhibition and hypoxia-induced pulmonary hypertension: effects on pulmonary vascular remodeling and contractility. Trends Cardiovasc Med 2009 19:31-37

31. Steudel W, Scherrer-Crosbie M, Bloch KD, Weimann J, Huang PL, Jones RC, Picard MH, Zapol WM: Sustained pulmonary hypertension and right ventricular hypertrophy after chronic hypoxia in mice with congenital deficiency of nitric oxide synthase 3. J Clin Invest 1998 101:2468-2477

32. Steiner MK, Syrkina OL, Kolliputi N, Mark EJ, Hales CA, Waxman AB: Interleukin-6 overexpression induces pulmonary hypertension. Circ Res 2009, 104:236-244

33. Dempsey EC, Wick MJ, Karoor V, Barr EJ, Tallman DW, Wehling CA, Walchak SJ, Laudi S, Le M, Oka M, Majka S, Cool CD, Fagan KA Klemm DJ, Hersh LB, Gerard NP, Gerard C, Miller YE: Neprilysin null mice develop exaggerated pulmonary vascular remodeling in response to chronic hypoxia. Am J Pathol 2009, 174:782-796

34. Hoshikawa Y, Voelkel NF, Gesell TL, Moore MD, Morris KG, Alger LA, Narumiya S, Geraci MW: Prostacyclin receptor-dependent modulation of pulmonary vascular remodeling. Am J Respir Crit Care Med 2001, 164:314-318

35. Guignabert C, Alvira CM, Alastalo TP, Sawada H, Hansmann G, Zhao M, Wang L, El-Bizri N, Rabinovitch M: Tie2-mediated loss of peroxisome proliferator-activated receptor- $\gamma$ in mice causes PDGF receptor- $\beta$-dependent pulmonary arterial muscularization. Am J Physiol Lung Cell Mol Physiol 2009, 297:L1082-L1090

36. Merklinger SL, Wagner RA, Spiekerkoetter E, Hinek A, Knutsen RH, Kabir MG, Desai K, Hacker S, Wang L, Cann GM, Ambartsumian NS, Lukanidin E, Bernstein D, Husain M, Mecham RP, Starcher B, Yanagisawa $\mathrm{H}$, Rabinovitch M: Increased fibulin-5 and elastin in S100A4/ Mts1 mice with pulmonary hypertension. Circ Res 2005, 97:596-604

37. Said SI, Hamidi SA, Dickman KG, Szema AM, Lyubsky S, Lin RZ, Jiang YP, Chen JJ, Waschek JA, Kort S: Moderate pulmonary arterial hypertension in male mice lacking the vasoactive intestinal peptide gene. Circulation 2007, 115:1260-1268

38. Angelini DJ, Su Q, Yamaji-Kegan K, Fan C, Skinner JT, Champion HC, Crow MT, Johns RA: Hypoxia-induced mitogenic factor (HIMF/FIZZ1/ RELM $\alpha$ ) induces the vascular and hemodynamic changes of pulmonary hypertension. Am J Physiol Lung Cell Mol Physiol 2009, 296:L582-L593

39. Khalil HM, el-Missiry AG, Abdalla HM, Khalil NM, Sabry NM, Abdel-
Atty HE, Tamara FA, el-Tayeb M, Zakaria NM: Serum levels of tumour necrosis factor- $\alpha$ in schistosomiasis mansoni and their analogous changes in collagen diseases and schistosomal arthropathy. J Egypt Soc Parasitol 1995, 25:427-436

40. Silva-Teixeira DN, Contigli C, Lambertucci JR, Serufo JC, Rodrigues $\mathrm{V}_{\text {,: }}$ Jr.: Gender-related cytokine patterns in sera of schistosomiasis patients with Symmers' fibrosis. Clin Diagn Lab Immunol 2004, 11:627-630

41. Fujita M, Mason RJ, Cool C, Shannon JM, Hara N, Fagan KA: Pulmonary hypertension in TNF- $\alpha$-overexpressing mice is associated with decreased VEGF gene expression. J Appl Physiol 2002, 93:21622170

42. Henriques-Coelho T, Brandao-Nogueira A, Moreira-Goncalves D, Correia-Pinto J, Leite-Moreira AF: Effects of TNF- $\alpha$ blockade in monocrotaline-induced pulmonary hypertension. Rev Port Cardiol 2008, 27:341-348

43. Raidl M, Sibbing B, Strauch J, Muller K, Nemat A, Schneider PM, Hag $\mathrm{H}$, Erdmann $\mathrm{E}$, Koch A: Impaired TNF $\alpha$-induced VEGF expression in human airway smooth muscle cells from smokers with COPD: role of MAPkinases and histone acetylation-effect of dexamethasone. Cell Biochem Biophys 2007, 49:98-110

44. Arcot SS, Lipke DW, Gillespie MN, Olson JW: Alterations of growth factor transcripts in rat lungs during development of monocrotalineinduced pulmonary hypertension. Biochem Pharmacol 1993, 1946: 1086-1091

45. Thomas M, Docx C, Holmes AM, Beach S, Duggan N, England K, Leblanc C, Lebret C, Schindler F, Raza F, Walker C, Crosby A, Davies RJ, Morrell NW, Budd DC: Activin-like kinase 5 (ALK5) mediates abnormal proliferation of vascular smooth muscle cells from patients with familial pulmonary arterial hypertension and is involved in the progression of experimental pulmonary arterial hypertension induced by monocrotaline. Am J Pathol 2009, 174:380-389

46. Chiaramonte MG, Mentink-Kane M, Jacobson BA, Cheever AW, Whitters MJ, Goad ME, Wong A, Collins M, Donaldson DD, Grusby MJ, Wynn TA: Regulation and function of the interleukin 13 receptor $\alpha 2$ during a T helper cell type 2-dominant immune response. J Exp Med 2003, 197:687-701

47. Chiaramonte MG, Schopf LR, Neben TY, Cheever AW, Donaldson DD, Wynn TA: IL-13 is a key regulatory cytokine for Th2 cell-mediated pulmonary granuloma formation and IgE responses induced by Schistosoma mansoni eggs. J Immunol 1999, 162:920-930

48. Fichtner-Feigl S, Strober W, Kawakami K, Puri RK, Kitani A: IL-13 signaling through the IL-13 $\alpha 2$ receptor is involved in induction of TGF- $\beta 1$ production and fibrosis. Nat Med 2006, 12:99-106

49. Jin N, Hatton N, Swartz DR, Xia X, Harrington MA, Larsen SH, Rhoades RA: Hypoxia activates jun-N-terminal kinase, extracellular signal-regulated protein kinase, and p38 kinase in pulmonary arteries. Am J Respir Cell Mol Biol 2000, 23:593-601

50. Welsh DJ, Peacock AJ, MacLean M, Harnett M: Chronic hypoxia induces constitutive p38 mitogen-activated protein kinase activity that correlates with enhanced cellular proliferation in fibroblasts from rat pulmonary but not systemic arteries. Am J Respir Crit Care Med 2001, 164:282-289

51. Long L, Crosby A, Yang X, Southwood M, Upton PD, Kim DK, Morrell NW: Altered bone morphogenetic protein and transforming growth factor- $\beta$ signaling in rat models of pulmonary hypertension: potential for activin receptor-like kinase- 5 inhibition in prevention and progression of disease. Circulation 2009, 119:566-576

52. Lee CG, Homer RJ, Zhu Z, Lanone S, Wang X, Koteliansky V, Shipley JM, Gotwals P, Noble P, Chen Q, Senior RM, Elias JA: Interleukin-13 induces tissue fibrosis by selectively stimulating and activating transforming growth factor $\beta_{1}$. J Exp Med 2001, 194:809-821

53. Kaviratne M, Hesse M, Leusink M, Cheever AW, Davies SJ, McKerrow $\mathrm{JH}$, Wakefield LM, Letterio JJ, Wynn TA: IL-13 activates a mechanism of tissue fibrosis that is completely TGF- $\beta$ independent. $\mathrm{J}$ Immunol 2004, 173:4020-4029 